\title{
Fisetin inhibits vascular endothelial growth factor-induced angiogenesis in retinoblastoma cells
}

\author{
LIANGJUN WANG ${ }^{1}$, NING $\mathrm{CHEN}^{2}$ and HONGXIA CHENG ${ }^{2}$ \\ ${ }^{1}$ Department of Ophthalmology, Yantai Mountain Hospital, Yantai, Shandong 264001; \\ ${ }^{2}$ Department of Ophthalmology, Yuhuangding Hospital, Yantai, Shandong 264000, P.R. China
}

Received June 26, 2018; Accepted May 1, 2019

DOI: $10.3892 /$ ol.2020.11679

\begin{abstract}
Fisetin is a small phytochemical molecule with antitumor activity. Angiogenesis is a basic process that occurs during tumor growth and metastasis. The vascular endothelial growth factor (VEGF)/VEGF receptor (VEGFR) pathway is a key regulator of angiogenesis. The aim of the present study was to evaluate whether fisetin affects angiogenesis through the VEGFR pathway. In the present study, Y79 cells were treated with $100 \mathrm{ng} / \mathrm{ml}$ VEGF in the presence of fisetin at concentrations of $0,25,50$ and $100 \mu \mathrm{M}$. A Cell Counting Kit- 8 assay was used to detect proliferation and the Transwell and Matrigel assays were used to assess cell migration and invasion, respectively. Reverse transcription-quantitative polymerase chain reaction analysis was applied to measure the expression level of VEGFR mRNA and western blot analysis was used to measure the protein expression of VEGFR. An immunofluorescence assay was used to detect the expression of VEGFR. Angiogenesis in vitro was assessed by a tube formation assay. The results demonstrated that fisetin significantly inhibited the proliferation of Y79 cells in a time- and dose-dependent manner. Fisetin also inhibited the migration and invasion of Y79 cells in a dose-dependent manner. Furthermore, fisetin inhibited the expression of VEGFR in Y79 cells in a dose-dependent manner and tumor angiogenesis in vitro. Thus, fisetin was found to inhibit angiogenesis via inhibition of the VEGF/VEGFR signaling pathway, and could be used as a candidate drug to inhibit angiogenesis in retinoblastoma.
\end{abstract}

\section{Introduction}

The growth and metastasis of malignant tumors relies on angiogenesis $(1,2)$. When the tumor volume exceeds $2-3 \mathrm{~mm}^{3}$,

Correspondence to: Dr Liangjun Wang, Department of Ophthalmology, Yantai Mountain Hospital, 91 Jiefang Road, Zhifu, Yantai, Shandong 264001, P.R. China

E-mail: nm9694@163.com

Key words: fisetin, angiogenesis, retinoblastoma, vascular endothelial growth factor, vascular endothelial growth factor receptor due to the ensuing ischemia and hypoxia, new capillaries are generated to maintain tumor growth $(3,4)$. An abundance of blood vessels may provide enough nutrients to the tumor tissue and remove various degradation products, and tumor cells can also undergo hematogenous metastasis after they enter the circulation via the blood vessels; otherwise, the tumor may undergo degenerative necrosis (5). The proliferation, invasion and metastasis of malignant tumors are closely related to tumor-induced angiogenesis $(1,2)$. Neovascularization provides sufficient oxygen and nutrients for the proliferation, infiltration and metastasis of tumor cells (2). In previous years, vascular endothelial growth factor (VEGF) and its receptor (VEGFR) have been identified as the major pathway involved in angiogenesis, and also serve an important role in tumor growth $(6,7)$. Therefore, inhibition of angiogenesis by targeting VEGF is a promising strategy for cancer chemoprevention and treatment $(8,9)$.

A number of phytochemicals have been shown to inhibit tumor angiogenesis in vitro and in vivo (10-13). Fisetin $\left(3,3^{\prime}, 4^{\prime}, 7\right.$-tetrahydroxyflavone), is an effective compound extracted from the lacquer family Rhus succedanea. This compound is also found in vegetables and fruits, such as apples, persimmons, grapes, kiwi, strawberries, onions and cucumbers (14). Fisetin has antioxidative, anti-inflammatory and other pharmacological properties $(15,16)$; its molecular formula is $\mathrm{C}_{15} \mathrm{H}_{10} \mathrm{O}_{6}$ and its molecular weight is 286.23. Fisetin has been shown to regulate different pathways of activation in various cancer cells (17-20): It has been reported to induce apoptosis and cell cycle arrest and inhibit androgen receptor signaling and growth of human prostate tumor xenografts (18); fisetin induces apoptosis and suppresses Wnt/epidermal growth factor receptor/nuclear factor-кB signaling in colon cancer cells (20); it induces apoptosis through activation of the caspase- 3 cascade and alternative expression of $\mathrm{p} 21$ protein in the human hepatocellular carcinoma cell line, SK-HEP-1 (21). Of note, in HCT-116 human colon cancer cells, fisetin-induced apoptosis is associated with elevated p53 levels (22); however, to the best of our knowledge, the role of fisetin in human retinoblastoma Y79 cells has not yet been investigated. The aim of the present study was to determine whether fisetin affects the angiogenic ability of Y79 cells, based on the findings of previous studies reporting that it plays a key role in inhibiting tumor cell invasion and migration $(19,23)$. 


\section{Materials and methods}

Cell line and reagents. The human retinoblastoma Y79 cell line $\left(\mathrm{ATCC}^{\circledR}\right.$ HTB-18 ${ }^{\mathrm{TM}}$ ) was obtained from the American Type Culture Collection and cultured in RPMI-1640 medium supplemented with $10 \%$ fetal bovine serum (both Invitrogen; Thermo Fisher Scientific, Inc.) under standard culture conditions $\left(37^{\circ} \mathrm{C}, 95 \%\right.$ humidified air and $5 \% \mathrm{CO}_{2}$ ). Rabbit anti-VEGFR antibody was purchased from Abcam (clone Y103; cat. no. ab32152). 4',6-diamidino-2-phenylindole (DAPI) was purchased from Sigma-Aldrich; Merck KGaA, Darmstadt, Germany. The enhanced chemiluminescence detection system was from Pierce; Thermo Fisher Scientific, Inc. Fisetin (cat. no. F4043) was obtained from Sigma-Aldrich; Merck KGaA, and dissolved in dimethyl sulfoxide (DMSO) as a stock solution. Matrigel was obtained from Thermo Fisher Scientific, Inc. and the Cell Counting Kit-8 (CCK-8) was purchased from MedChemExpress LLC. Specific primers for the reverse transcription-quantitative polymerase chain reaction (RT-qPCR) were obtained from Takara Bio, Inc.

Cell viability and proliferation assays. The Y79 cells in the logarithmic growth phase were harvested, digested with $0.25 \%$ trypsin, added to RPMI-1640 medium containing 10\% serum to prepare a cell suspension of $1 \times 10^{8} / \mathrm{ml}$, plated in 96-well cell culture plates, with $90 \mu \mathrm{l}$ per well (blank wells contained an equal volume of RPMI-1640 complete medium), and incubated at $37^{\circ} \mathrm{C}$ in a $5 \% \mathrm{CO}_{2}$ incubator for $24 \mathrm{~h}$, until the cells grew into a monolayer. Subsequently, $10 \mu \mathrm{l}$ of fisetin were added at final concentrations of 25,50 and $100 \mu \mathrm{M}$ with $100 \mu \mathrm{g} / \mathrm{ml}$ VEGF (cat. no. HPLC-11066-HNAH; Sino Biological). The negative control comprised an equal volume of DMSO with $100 \mu \mathrm{g} / \mathrm{ml}$ VEGF. Fisetin was added to the cells for 24,48 and $72 \mathrm{~h}$. CCK-8 $10 \mu \mathrm{l}$ was added to each well for $1 \mathrm{~h}$. The absorbance value of each well was measured with an enzyme-linked immunosorbent detector at a wavelength of $450 \mathrm{~nm}$. The inhibition rate was calculated by the following formula: Proliferation inhibition rate $=\left[1-\left(\mathrm{OD}_{\text {administration group }}-\mathrm{OD}_{\text {blank well }}\right) /\left(\mathrm{OD}_{\text {negative control group }}-\right.\right.$ $\left.\left.\mathrm{OD}_{\text {blank well }}\right)\right] \times 100 \%$, and the LOGIT method was used to calculate the half-maximal inhibitory concentration $\left(\mathrm{IC}_{50}\right)$.

In vitro migration and invasion assay. For Transwell migration assays, $5 \times 10^{4}$ Y79 cells were plated in the top chamber with a non-coated membrane (24-well insert; pore size, $8 \mu \mathrm{m}$; BD Biosciences) and treated with $100 \mu \mathrm{g} / \mathrm{ml} \mathrm{VEGF}$ and fisetin at concentrations of $0,25,50$ and $100 \mu \mathrm{M}$ at $37^{\circ} \mathrm{C}$ for $4 \mathrm{~h}$. For the invasion assays, $1.25 \times 10^{5} \mathrm{Y} 79$ cells were plated in the top chamber with a Matrigel-coated membrane (24-well insert; pore size, $8 \mu \mathrm{m}$; BD Biosciences) and treated with $100 \mu \mathrm{g} / \mathrm{ml}$ VEGF and fisetin at concentrations of $0,25,50$ and $100 \mu \mathrm{M}$ at $37^{\circ} \mathrm{C}$ for $4 \mathrm{~h}$. In both assays, the cells were plated in medium without serum or growth factors, and medium supplemented with serum was used as a chemoattractant in the lower chamber. The cells were incubated at $37^{\circ} \mathrm{C}$ for $24 \mathrm{~h}$ and cells that did not migrate or invade through the pores were removed using a cotton swab. Cells on the lower surface of the membrane were stained with the Diff-Quick Staining Set (Dade Behring; Siemens Healthineers) for $1 \mathrm{~min}$ at $25^{\circ} \mathrm{C}$ and counted under inverted fluorescence microscopy (magnification, x100; IX81; Olympus Corporation).

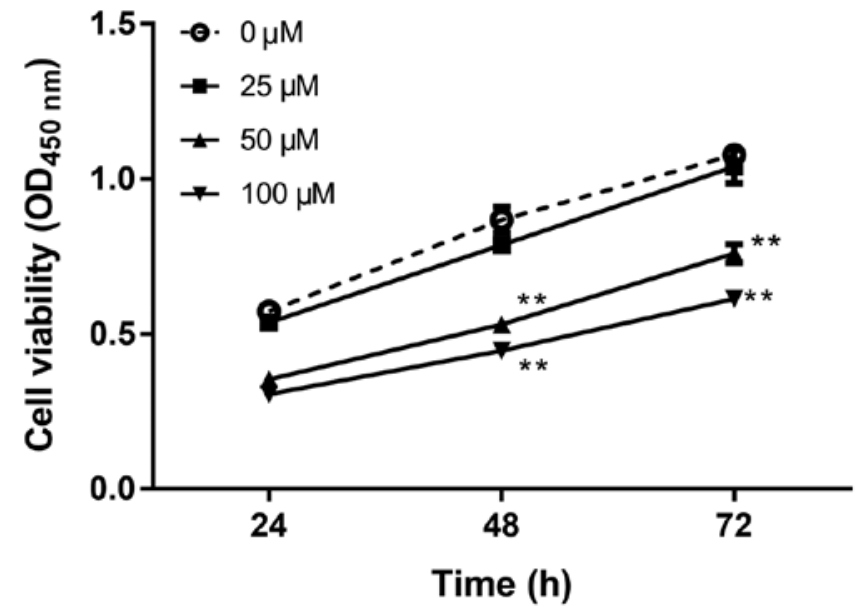

Figure 1. Viability of Y79 cells. Y79 cells were treated with $100 \mu \mathrm{g} / \mathrm{ml}$ vascular endothelial growth factor and fisetin at concentrations of $0,25,50$ and $100 \mu \mathrm{M}$ for 24,48 and $72 \mathrm{~h}$. ${ }^{* *} \mathrm{P}<0.05$ vs. $0 \mu \mathrm{M}$. OD, optical density.

In vitro angiogenesis assay. Tube formation was assessed by an in vitro angiogenesis assay. Y79 cells $\left(4 \times 10^{5}\right)$ were plated in 6-well plates pre-coated with Matrigel for $8 \mathrm{~h}$ in the presence of $100 \mu \mathrm{M}$ fisetin with $100 \mu \mathrm{g} / \mathrm{ml}$ VEGF in RPMI-1640 medium. Then, tube formation and tube length were observed by inverted fluorescence microscopy (magnification, x100; IX81; Olympus Corporation) and analyzed by ImageJ software (version 1.4; National Institutes of Health).

$R T$-qPCR analysis. Y79 cells were plated in culture plates under normal growth conditions. When the cell density reached $70 \%$, the cells were treated with $50 \mu \mathrm{M}$ fisetin in DMSO vehicle control or RPMI-1640 medium supplemented with $10 \%$ serum. Extraction of total RNA was performed using TRIzol ${ }^{\circledR}$ (Invitrogen; Thermo Fisher Scientific, Inc.). Reverse transcription was performed using the iScript cDNA Synthesis kit (Bio-Rad Laboratories, Inc.) with the following thermal protocol: $5 \mathrm{~min}$ at $25^{\circ} \mathrm{C}, 30 \mathrm{~min}$ at $42^{\circ} \mathrm{C}$ and $5 \mathrm{~min}$ at $85^{\circ} \mathrm{C}$. The $\mathrm{qPCR}$ reaction was run on an ABI $7900 \mathrm{HT}$ Fast Real-Time PCR system (Applied Biosystems; Thermo Fisher Scientific, Inc.) using iTaq ${ }^{\mathrm{TM}} \mathrm{SYBR}^{\circledR}$ Green Supermix with ROX (Bio-Rad Laboratories, Inc.) under the following thermocycling conditions: $50^{\circ} \mathrm{C}$ for $2 \mathrm{~min}$ and $95^{\circ} \mathrm{C}$ for $10 \mathrm{~min}$ preheating, followed by 40 cycles of $92^{\circ} \mathrm{C}$ for $15 \mathrm{sec}$ and $60^{\circ} \mathrm{C}$ for $1 \mathrm{~min}$. GAPDH was used as the internal reference gene. There were three replicates for each sample selected for diversity. The relative quantification results were analyzed by the $2^{-\Delta \Delta \mathrm{Cq}}$ method (24). The primers used were as follows: VEGFR forward, 5'-CTCTCTCTGCCTACCTCACCTG-3'; and reverse, 5'-CGGCTCTTTCGCTTACTGTTC-3'; and GAPDH forward, 5'-TGTTCGTCATGGGTGTGAA-3'; and reverse, 5'-ATGGCATGGACTGTGGTCAT-3'.

Immunoblot analysis. Y79 cells were cultured in RPMI-1640 medium containing $0,25,50$ or $100 \mu \mathrm{M}$ fisetin with $100 \mu \mathrm{g} / \mathrm{ml} \mathrm{VEGF}$ for $24 \mathrm{~h}$ at $37^{\circ} \mathrm{C}$. The cells were lysed on ice in $100 \mu$ l RIPA buffer containing a protease and phosphatase inhibitor cocktail (Pierce; Thermo Fisher Scientific, Inc.). After centrifugation at $10,000 \mathrm{x}$ g for $20 \mathrm{~min}$ at $4^{\circ} \mathrm{C}$, an equal amount $(20-30 \mu \mathrm{g})$ of protein, quantified using a BCA 

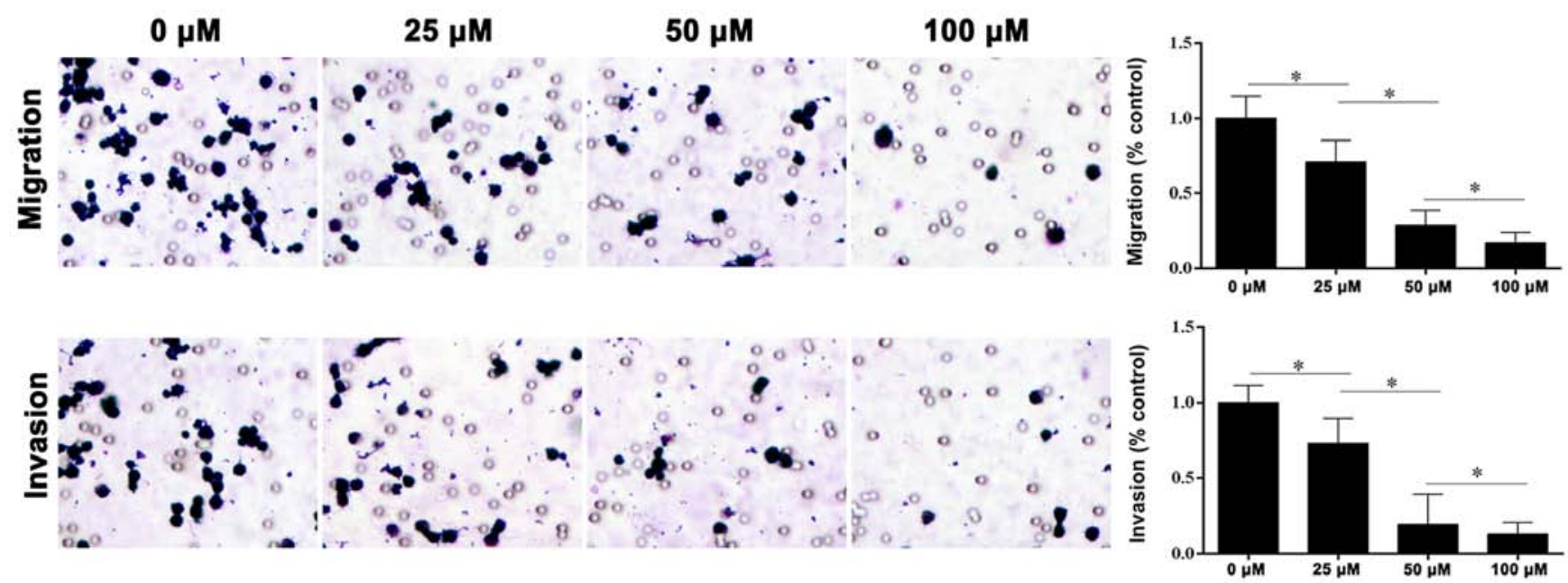

Figure 2. Invasion and migration of Y79 cells. Y79 cells were treated with $100 \mu \mathrm{g} / \mathrm{ml}$ vascular endothelial growth factor, and fisetin at concentrations of 0,25 , 50 and $100 \mu \mathrm{M}$, respectively. Magnification, $\mathrm{x} 100$. ${ }^{\mathrm{P}} \mathrm{P}<0.05$.

Protein Assay kit (Beyotime Institute of Biotechnology), was subjected to $4-12 \%$ Bis-Tris SDS-PAGE (Invitrogen; Thermo Fisher Scientific, Inc.). The proteins were then blotted onto Immobilon-P PVDF membranes (EMD Millipore). After blocking with 3\% skimmed milk powder for $1 \mathrm{~h}$ at room temperature, the membranes were incubated with the primary anti-VEGFR antibody $(1: 1,000)$ in PBS containing $0.01 \%$ Tween 20 overnight at $4^{\circ} \mathrm{C}$. The membranes were then incubated with goat anti-rabbit horseradish peroxidase-conjugated secondary antibody (1:500; cat. no. BA1056; Wuhan Boster Biological Technology, Ltd.) for $1 \mathrm{~h}$ at $25^{\circ} \mathrm{C}$, followed by the addition of SuperSignal enhanced chemiluminescent substrate to stabilize the peroxide solution, and detected with Biomax-MR membrane (Kodak). Protein expression was quantified and analyzed using ImageJ software (version 1.4).

Immunohistochemistry. The Y79 cells were cultured in RPMI-1640 medium containing $0,25,50$ or $100-\mu \mathrm{M}$ fisetin and $100 \mu \mathrm{g} / \mathrm{ml} \mathrm{VEGF}$, for $24 \mathrm{~h}$ at $37^{\circ} \mathrm{C}$. Cells were fixed in $4 \%$ formaldehyde at $4^{\circ} \mathrm{C}$ for $10 \mathrm{~min}$ (Sigma-Aldrich; Merck KGaA). The cells were blocked with $3 \%$ BSA (Beijing Solarbio Science \& Technology Co., Ltd.) for $1 \mathrm{~h}$ at $37^{\circ} \mathrm{C}$, incubated with the anti-VEGFR primary antibody $(1: 100)$ overnight at $4^{\circ} \mathrm{C}$, and then incubated with Alexa Fluor ${ }^{\circledR} 488$ goat anti-rabbit IgG $\mathrm{H}+\mathrm{L}$ secondary antibody (1:500, cat. no. ab150077; Abcam) for $30 \mathrm{~min}$, at $37^{\circ} \mathrm{C}$. The cells were counterstained with DAPI $(10 \mu \mathrm{g} / \mathrm{ml})$ to label the nuclei at $25^{\circ} \mathrm{C}$ for $5 \mathrm{~min}$. The cells were observed by inverted fluorescence microscopy (magnification, x100; IX81; Olympus Corporation) and analyzed by ImageJ software (version 1.4).

Statistical analysis. Statistical analyses were conducted using SPSS software (version 22.0; IBM Corp.). Data presented as the mean \pm standard deviation of three independent experiments. The statistical significance of the differences between the control and the different treatment groups was determined by one-way analysis of variance with Tukey's post hoc test. $\mathrm{P}<0.05$ was considered to indicate a statistically significant difference.
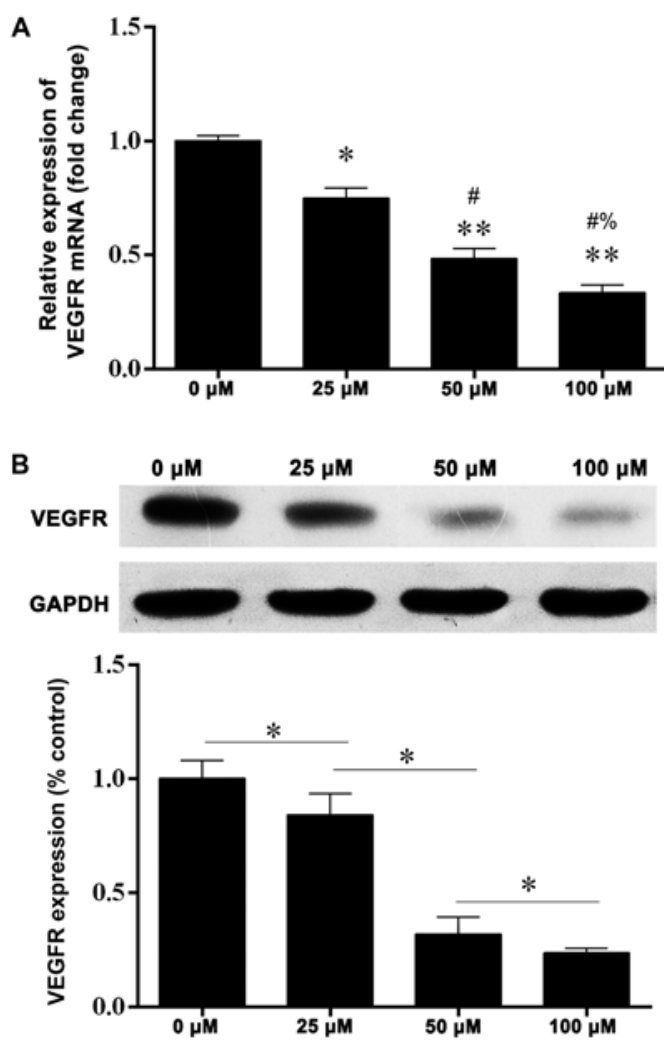

Figure 3. VEGFR expression in Y79 cells. Y79 cells were treated with $100 \mu \mathrm{g} / \mathrm{ml}$ VEGF and fisetin at concentrations of $0,25,50$ and $100 \mu \mathrm{M}$. (A) Quantitative analysis results of the relative expression difference of VEGFR in the treatment groups using reverse transcription-quantitative polymerase chain reaction analysis. ${ }^{*} \mathrm{P}<0.05,{ }^{* *} \mathrm{P}<0.01$ vs. control group; ${ }^{\#} \mathrm{P}<0.05$ vs. $25 \mu \mathrm{M}$ group; ${ }^{\%} \mathrm{P}<0.05$ vs. $50 \mu \mathrm{M}$ group. (B) $\mathrm{Y} 79$ cells were incubated with $0,25,50$ or $100 \mu \mathrm{M}$ fisetin with $100 \mathrm{ng} / \mathrm{ml}$ VEGF. Protein expression of VEGFR was determined by western blotting. ${ }^{*} \mathrm{P}<0.05$. VEGF, vascular endothelial growth factor; VEGFR, VEGF receptor.

\section{Results}

Fisetin inhibits Y79 cell growth and proliferation. To assess the effect of fisetin on the growth and proliferation on Y79 cells, the cells were treated with $100 \mu \mathrm{g} / \mathrm{ml} \mathrm{VEGF,} \mathrm{and} \mathrm{fisetin}$ 


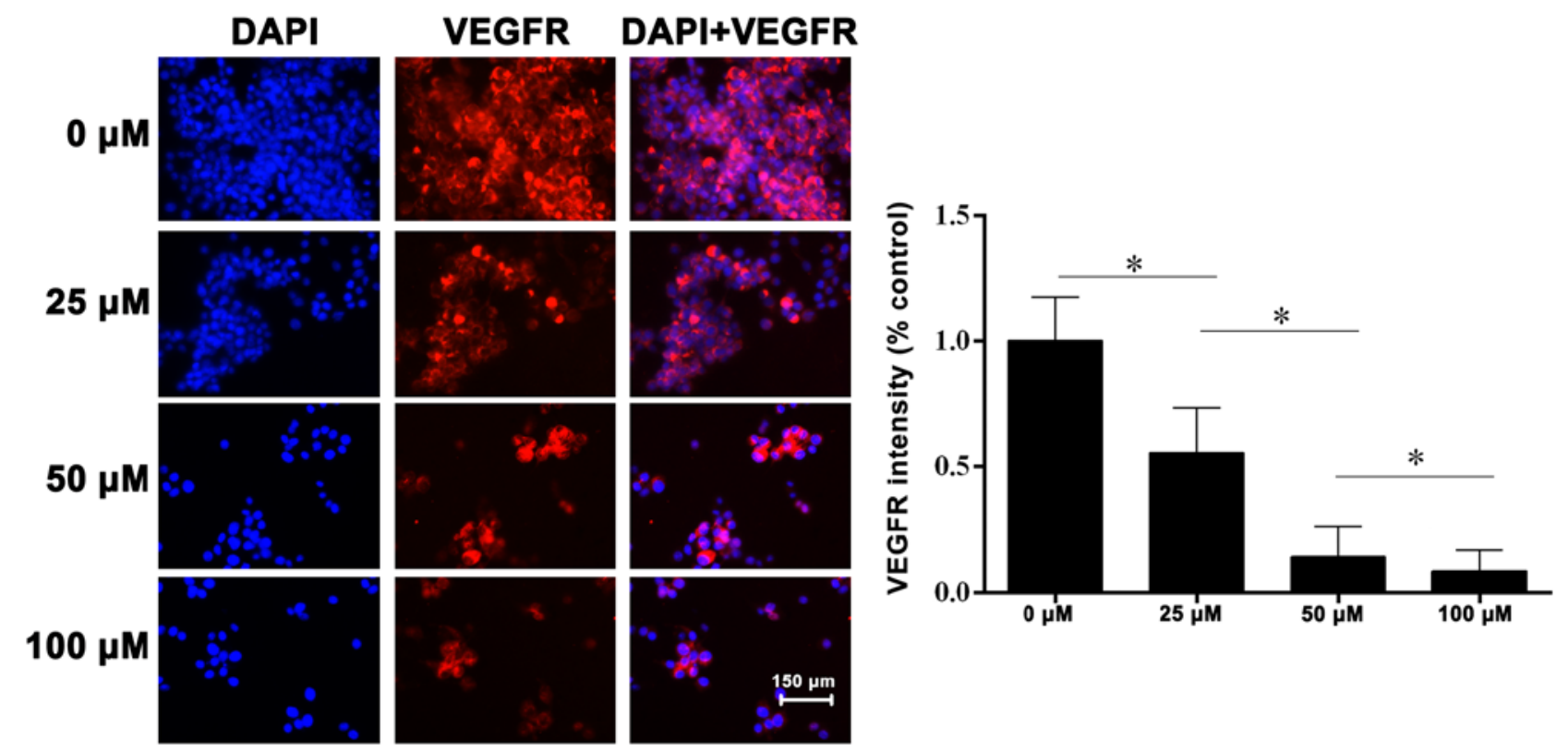

Figure 4. VEGFR immunofluorescence staining of Y79 cells. Y79 cells were treated with $100 \mu \mathrm{g} / \mathrm{ml}$ VEGF and fisetin at concentrations of $0,25,50$ and $100 \mu \mathrm{M}$. Scale bar, $150 \mu \mathrm{m}$. "P<0.05. VEGF, vascular endothelial growth factor; VEGFR, VEGF receptor; DAPI, 4',6-diamidino-2-phenylindole.

at concentrations of $0,25,50$ and $100 \mu \mathrm{M}$. The results demonstrated that fisetin inhibited Y79 cell viability and proliferation in a time- and dose-dependent manner. Compared with the control group, there was a statistically significant difference in total Y79 cell reduction between 48 and $72 \mathrm{~h}$ at 50 and $100 \mu \mathrm{M}$ fisetin treatment $(\mathrm{P}<0.01)$. The results indicated that fisetin inhibited Y79 cell viability and proliferation (Fig. 1).

Fisetin inhibits Y79 cell invasion and migration. To assess the effect of fisetin on the invasion and migration on Y79 cells, the cells were treated with $100 \mu \mathrm{g} / \mathrm{ml} \mathrm{VEGF}$ and $0,25,50$ and $100 \mu \mathrm{M}$ fisetin. The results demonstrated that fisetin inhibited the invasion and migration of Y79 cells in a dose-dependent manner (Fig. 2).

Fisetin inhibits VEGFR expression in Y79 cells. In order to verify whether fisetin affects angiogenesis in Y79 cells through the VEGF/VEGFR pathway, VEGFR expression was detected at the protein and mRNA level. The results demonstrated that fisetin affected the expression of VEGFR, and this effect occurred in a dose-dependent manner (Fig. 3). Therefore, fisetin downregulated the expression of VEGFR in Y79 cells.

Validation of the role of fisetin in Y79 cells. To confirm the role of fisetin in Y79 cells, immunofluorescence staining of VEGFR was performed. The results demonstrated that fisetin downregulated the expression of VEGFR and inhibited cell proliferation in a dose-dependent manner (Fig. 4). In addition. fisetin treatment inhibited tube formation and was associated with shorter tube length (Fig. 5). Thus, fisetin effectively inhibited VEGFR expression and angiogenesis in Y79 cells.

\section{Discussion}

The present study demonstrated that fisetin inhibits angiogenesis in Y79 cells. Under conditions of VEGF induction, fisetin

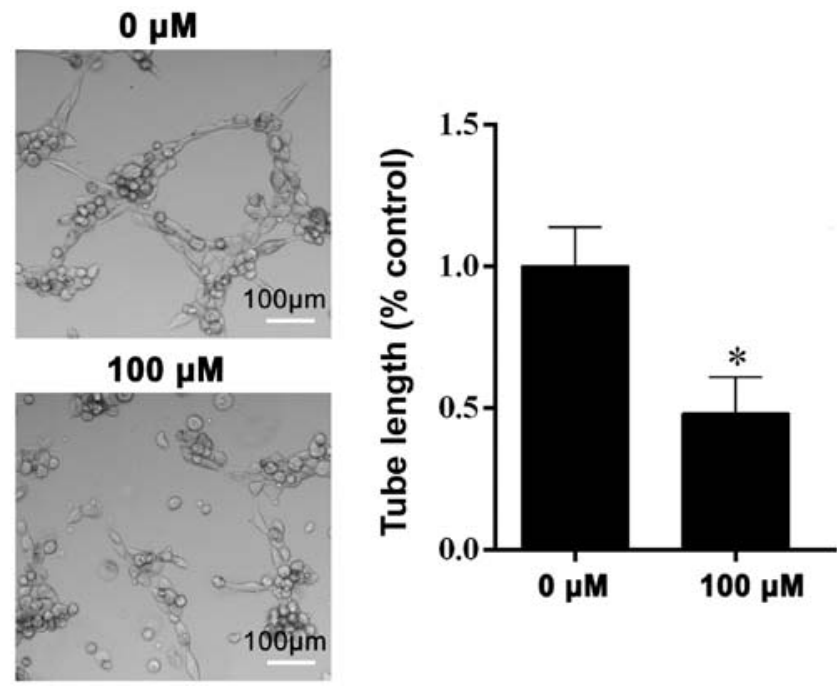

Figure 5. Tube-formation ability of Y79 cells. Y79 cells were treated with $100 \mu \mathrm{g} / \mathrm{ml}$ vascular endothelial growth factor and fisetin at concentrations of $0,25,50$ and $100 \mu \mathrm{M}$. Scale bar, $100 \mu \mathrm{m}$. ${ }^{*} \mathrm{P}<0.05$.

affected the activity of Y79 cells. In vitro Matrigel-Transwell assays indicated that the ability of Y79 cells to invade and migrate under conditions induced by VEGF was inhibited. In addition, the tube-formation assay showed that their angiogenic capacity was also inhibited. Angiogenesis is a basic process during tumor growth and metastasis that is closely associated with poor prognosis and survival (25). In the present study, fisetin was found to inhibit angiogenesis in Y79 cells, and we hypothesized that this effect was mediated by inhibiting the expression of VEGFR. It has been reported that there are three main pathways for inhibiting tumor proliferation and angiogenesis through the VEGF/VEGFR signaling pathway (26): i) By inhibiting the expression of VEGF mRNA, reducing the synthesis and secretion of VEGF; ii) by directly reducing 
VEGFR expression, thereby inhibiting the binding of VEGF to its receptor; and iii) by directly binding to the VEGF receptor to antagonize the pro-angiogenic effects of VEGF and inhibit tumor growth. Based on this hypothesis, the changes in protein and gene levels by immunofluorescence were investigated. In the present study, it was demonstrated that fisetin downregulated the expression of VEGFR. Different concentrations of fisetin exerted a dose-dependent effect on VEGFR expression. The CCK-8 assay revealed that fisetin exerts cytotoxic effects on Y79 cells and can affect cell survival rate. Previous studies have reported that fisetin exerts a strong inhibitory effect on several tumor types $(18,19)$. This is consistent with the findings from the present study, indicating that fisetin may be a candidate drug for the treatment of retinoblastoma.

The growth and development of solid tumors relies heavily on angiogenic processes mediated by pro-angiogenic factors derived from tumor cells and the microenvironment $(27,28)$. Therefore, targeting these processes may be a potential strategy for inhibiting tumor growth and metastasis $(29,30)$. In the present study, fisetin was found to affect Y79 cell proliferation, survival, migration and vascular tube formation. These effects of fisetin may be due to the downregulation of protein expression leading to activation of the caspase pathway as a potential mechanism of inhibition of human endothelial cell survival (31). Poly(ADP-ribose) polymerase is involved in DNA repair, stability and other cellular events, and is cleaved by caspase family members $(89 \mathrm{kDa})$, marking caspasedependent apoptosis (32).

VEGF is the most potent and specific tumor-promoting angiogenic factor. As an angiogenic factor and mitogen of endothelial cells, it can directly or indirectly participate in angiogenesis (2). It plays an important role in the formation and growth of orthotopic tumors, as well as the development of metastases (33). VEGF is highly expressed during tumor growth $(28,34)$ and its downregulation is considered as a potential strategy for the prevention and control of cancer (8). The VEGF receptor family includes VEGFR-1, also known as fms-related tyrosine kinase-1 (Flt-1), VEGFR-2 (kinase insert domain receptor; KDR) and VEGFR-3 (fms-like tyrosine kinase-4), all of which have tyrosine kinase activity $(5,6,8,10)$. VEGF binding to KDR may induce the proliferation of vascular endothelial cells $(5,6)$; the binding of VEGF to Flt-1 causes the formation of tubular-like structures and endothelial cell migration (2). VEGF is generally considered to exert its effects on tumor cells through a paracrine mechanism (28). As tumor cells lack VEGFR, they cannot respond to self-secreted VEGF (28). Endothelial cells involved in angiogenesis express large amounts of VEGFR and generally secrete small amounts of VEGF, whereas its secretion is increased during anti-angiogenesis therapy (2). However, a previous study found that VEGF secreted by tumor cells can promote the formation of blood vessels through paracrine mechanisms (35); furthermore, VEGF binds to VEGFR through an autocrine mode of action, thereby directly promoting the proliferation of tumor cells $(6,7)$. Certain studies have demonstrated that VEGFR is expressed not only in vascular endothelial cells, but also in several types of tumor cells, such as primary liver cancer, ovarian granulosa cell tumor and breast cancer $(25,28,29)$. Primary liver cancer is an angiogenic tumor, which was ranked as the third most common cause of cancer-associated mortality in China in 2018 (36).
The present study demonstrated that fisetin can affect tumor growth and angiogenesis, and these effects could be mediated by the VEGF/VEGFR signaling pathway. Therefore, fisetin may be used as a candidate drug to inhibit angiogenesis in retinoblastoma by targeting VEGF/VEGFR signaling. However, the underlying mechanism requires further investigation.

\section{Acknowledgements}

Not applicable.

\section{Funding}

No funding was received.

\section{Availability of data and materials}

The datasets used/or analyzed during the present study are available from the corresponding author on reasonable request.

\section{Authors' contributions}

LW was responsible for the study design and the acquisition of data. NC performed the data analysis. LW and HC performed the functional experiments. All authors revised the manuscript and have approved its final version.

\section{Ethics approval and consent to participate}

Not applicable.

\section{Patient consent for publication}

Not applicable.

\section{Competing interests}

The authors declare that they have no competing interests.

\section{References}

1. Shchyogolev AI, Dubova EA and Tumanova UN: Vascularization of hepatocellular carcinoma tissue depends on its differentiation degree. Bull Exp Biol Med 153: 490-494, 2012 (In English, Russian).

2. Zeng Y, Yao X, Liu X, He X, LI L, Liu X, Yan Z, Wu J and Fu BM: Anti-angiogenesis triggers exosomes release from endothelial cells to promote tumor vasculogenesis. J Extracell Vesicles 8: 1629865, 2019.

3. Folkman J: Role of angiogenesis in tumor growth and metastasis. Semin Oncol 29 (6 Suppl 16): S15-S18, 2003.

4. Yan Z, Liu J, Xie L, Liu X and Zeng Y: Role of heparan sulfate in mediating CXCL8-induced endothelial cell migration. PeerJ 4: e1669, 2016.

5. Takayama K, Ueno H, Nakanishi Y, Sakamoto T, Inoue K, Shimizu K, Oohashi H and Hara N: Suppression of tumor angiogenesis and growth by gene transfer of a soluble form of vascular endothelial growth factor receptor into a remote organ. Cancer Res 60: 2169-2177, 2000.

6. Färkkilä A, Anttonen M, Pociuviene J, Leminen A, Butzow R Heikinheimo $M$ and Unkila-Kallio L: Vascular endothelial growth factor (VEGF) and its receptor VEGFR-2 are highly expressed in ovarian granulosa cell tumors. Eur J Endocrinol 164: 115-122, 2011. 
7. Guo S, Colbert LS, Fuller M, Zhang Y and Gonzalezperez RR: Vascular endothelial growth factor receptor-2 in breast cancer. Biochim Biophys Acta 1806: 108-121, 2010.

8. Bhat TA and Singh RP: Tumor angiogenesis-a potential target in cancer chemoprevention. Food Chem Toxicol 46: 1334-1345, 2008

9. Jung MH, Sun HL, Ahn EM and You ML: Decursin and decursinol angelate inhibit VEGF-induced angiogenesis via suppression of the VEGFR-2-signaling pathway. Carcinogenesis 30: 655-661, 2009.

10. Tosetti F, Ferrari N, De Flora S and Albini A: Angiopreventio: Angiogenesis is a common and key target for cancer chemopreventive agents. FASEB J 16: 2-14, 2002.

11. Albini A, Noonan DM and Ferrari N: Molecular pathways for cancer angioprevention. Clin Cancer Res 13: 4320-4325, 2007.

12. Fotsis T, Pepper MS, Aktas E, Breit S, Rasku S, Adlercreutz H, Wähälä K, Montesano R and Schweigerer L: Flavonoids, dietary-derived inhibitors of cell proliferation and in vitro angiogenesis. Cancer Res 57: 2916-2921, 1997.

13. Paper DH: Natural products as angiogenesis inhibitors. Planta Med 64: 686-695, 1998.

14. Adhami VM, Syed DN, Khan N and Mukhtar H: Dietary flavonoid fisetin: A novel dual inhibitor of PI3K/Akt and mTOR for prostate cancer management. Biochem Pharmacol 84: 1277-1281, 2012.

15. Park HH, Lee S, Oh JM, Lee MS, Yoon KH, Park BH, Kim JW, Song $\mathrm{H}$ and Kim SH: Anti-inflammatory activity of fisetin in human mast cells (HMC-1). Pharmacol Res 55: 31-37, 2007.

16. van Acker FA, Schouten O, Haenen GR, van der Vijgh WJ and Bast A: Flavonoids can replace alpha-tocopherol as an antioxidant. FEBS LETT 473: 145-148, 2000.

17. Khan N, Asim M, Afaq F, Abu ZM and Mukhtar H: A novel dietary flavonoid fisetin inhibits androgen receptor signaling and tumor growth in athymic nude mice. Cancer Res 68: 8555-8563, 2008.

18. Khan N, Afaq F, Syed DN and Mukhtar H: Fisetin, a novel dietary flavonoid, causes apoptosis and cell cycle arrest in human prostate cancer LNCaP cells. Carcinogenesis 29: 1049-1056, 2008.

19. Liao YC, Shih YW, Chao CH, Lee XY and Chiang TA: Involvement of the ERK signaling pathway in fisetin reduces invasion and migration in the human lung cancer cell line A549. J Agric Food Chem 57: 8933-8941, 2009.

20. Suh YS, Afaq F, Johnson JJ and Mukhtar H: A plant flavonoid fisetin induces apoptosis in colon cancer cells by inhibition of COX2 and Wnt/EGFR/NF-kappaB-signaling pathways. Carcinogenesis 30: 300, 2009.

21. Chen YC, Shen SC, Lee WR, Lin HY, Ko CH, Shih CM and Yang LL: Wogonin and fisetin induction of apoptosis through activation of caspase 3 cascade and alternative expression of p21 protein in hepatocellular carcinoma cells SK-HEP-1. Arch Toxicol 76: 351-359, 2002.

22. Lim DY and Park JH: Induction of p53 contributes to apoptosis of HCT-116 human colon cancer cells induced by the dietary compound fisetin. Am J Physiol Gastrointest Liver Physiol 296: G1060-G1068, 2009.
23. Si Y, Liu J, Shen H, Zhang C, Wu Y, Huang Y, Gong Z, Xue J and Liu T: Fisetin decreases TET1 activity and CCNY/CDK16 promoter $5 \mathrm{hmC}$ levels to inhibit the proliferation and invasion of renal cancer stem cell. J Cell Mol 23: 1095-1105, 2019.

24. Livak KJ and Schmittgen TD: Analysis of relative gene expression data using real-time quantitative PCR and the 2(-Delta Delta $\mathrm{C}(\mathrm{T})$ ) method. Methods 25: 402-408, 2001.

25. Zeng Y, Yao X, Chen L, Yan Z, Liu J, Zhang Y, Feng T, Wu J and Liu X: Sphingosine-1-phosphate induced epithelial-mesenchymal transition of hepatocellular carcinoma via an MMP-7/syndecan-1/TGF- $\beta$ autocrine loop. Oncotarget 7 : 63324-63337, 2016.

26. Chen C, Yu DC and Teng LS: Development of anti-tumor drugs targeting VEGF/VEGFR: a progress. Chin J Cancer Biother 3: 291-295,300, 2007 (In Chinese).

27. Folkman J: Tumor angiogenesis: Therapeutic implications. N Engl J Med 285: 1182-1186, 1971.

28. Gupta MK and Qin RY: Mechanism and its regulation of tumor-induced angiogenesis. World J Gastroenterol 9: 1144-1155, 2003.

29. Cherrington JM, Strawn LM and Shawver LK: New paradigms for the treatment of cancer: The role of anti-angiogenesis agents. Adv Cancer Res 79: 1-38, 2000.

30. Grimm D, Bauer J and Schoenberger J: Blockade of neoangiogenesis, a new and promising technique to control the growth of malignant tumors and their metastases. Curr Vasc Pharmacol 7: 347-357, 2009.

31. Singh RP, Dhanalakshmi S, Agarwal C and Agarwal R: Silibinin strongly inhibits growth and survival of human endothelial cells via cell cycle arrest and downregulation of survivin, Akt and NF-kappaB: Implications for angioprevention and antiangiogenic therapy. Oncogene 24: 1188-1202, 2005.

32. Kaufmann SH, Desnoyers S, Ottaviano Y, Davidson NE and Poirier GG: Specific proteolytic cleavage of poly(ADP-ribose) polymerase: An early marker of chemotherapy-induced apoptosis. Cancer Res 53: 3976-3985, 1993.

33. Kraizer Y, Mawasi N, Seagal J, Paizi M, Assy N and Spira G: Vascular endothelial growth factor and angiopoietin in liver regeneration. Biochem Biophys Res Commun 287: 209-215, 2001.

34. Masood R, Cai J, Zheng T, Smith DL, Hinton DR and Gill PS: Vascular endothelial growth factor (VEGF) is an autocrine growth factor for VEGF receptor-positive human tumors. Blood 98: 1904, 2001.

35. Tian X, Song S, Wu J, Meng L, Dong Z and Shou C: Vascular endothelial growth factor: Acting as an autocrine growth factor for human gastric adenocarcinoma cell MGC803. Biochem Biophys Res Commun 286: 505-512, 2001.

36. Bray F, Ferlay J, Soerjomataram I, Siegel RL, Torre LA and Jemal A: Global cancer statistics 2018: GLOBOCAN estimates of incidence and mortality worldwide for 36 cancers in 185 countries. CA Cancer J Clin 68: 394-424, 2018.

This work is licensed under a Creative Commons Attribution-NonCommercial-NoDerivatives 4.0 International (CC BY-NC-ND 4.0) License. 